\title{
The Shifting Terms of Religious Authority in North Atlantic Politics and Culture
}

\author{
STEWART M. HOOVER \\ University of Colorado Boulder, USA
}

\begin{abstract}
Religion continues to evolve on both sides of the North Atlantic. In both contexts, traditional ways of understanding religion are confronted by new realities. The emerging and growing influence of modern media and media institutions are important causes of these changes. It is no longer possible to think of 'religion' and 'secular' as separate categories when 'secular' media increasingly define and deploy religious images, interests, and networks, displacing the influence of traditional authorities. The role of media in these trends is especially obvious in relation the emerging politics of populism, nationalism, and retrenchment. The media operate in a number of registers in these relations, including their textual, institutional, and practical dimensions.
\end{abstract}

KEYWORDS Religion, media, politics, nationalism

\section{Introduction}

It is increasingly clear that to understand religion in the twenty-first century, we must also understand media and the ways that religion and religions are being remade through their interaction with modern media. Recent political developments in the U.S. and in Europe have presented an ever more obvious case of the ways that new religious formations, particularly in the area of politics, are of increasing importance and that to understand them, we must account for their instantiation in modern media forms and channels. It is the purpose of this essay to present a historically rooted analysis from the perspective of media scholarship. This is not a complex religious history or a complex media history. Instead, I intend to present an integrated account of how religion and media have interacted in this evolving history.

Until the mid-twentieth century, both media and religion seemed to have achieved a kind of stability in the North Atlantic West. There were a few dominant media channels, and it was still possible to think of "religion" in terms of major confessional groups and their institutions. It was also common in that period to think of religion largely in terms of what we now know to be a too-simplistic definition of 'secularization.' As wealth, education, and general well-being 
seemed to be on the increase in the postwar period, it seemed likely that the long-predicted decline of religion would continue to move ahead (Berger, 1967). Religion was not only seen to be in decline within its own boundaries, its influence in other areas including politics, the economy, and the workplace was also seen to be in decline (Calhoun, Jurgensmeyer, and van Antwerpen 2011).

This picture began to change markedly later in the twentieth century, with two particularly notable developments. The first of these was the Islamic Revolution in Iran, where a oncesecular majority Muslim state-a bulwark of the West (and the U.S. in particular)—fell to a revolution based in religion, resulting in a theocracy. This was especially notable because it was so unexpected. The Western world was caught by surprise. Neither western journalists nor western foreign-affairs establishments anticipated that religion could be the cause of such a monumental change.

The other important development undermining the assumption of western secularization was the emergence, first in the U.S., and later spreading elsewhere in the world-even into Europe-of the movement we now call 'neo-Evangelicalism.' Prior to the 1970s, conservative Protestantism had been in decline, identified with the fundamentalism of the early twentieth century and thought to have been largely repudiated by an increasingly secular and moderate western culture. This new Evangelicalism became notable for its entrance into politics, something that was entirely new (Fea 2019). Evangelical leaders sought to reform society and politics, with the goal of reclaiming lost ground in the public sphere (Marsden 1984). The Evangelical revival also ushered in a range of other movements and circulations of religion, from the spread of urban "megachurches" to the growth Pentecostalism across the globe (Miller, Sargeant, and Flory 2013).

The turn of the new century brought in an entirely new instantiation of religion as the September 11 attacks in New York pushed Islam into global consciousness and global political discourse in entirely new ways. More than anything in decades, this put religion on national and international agendas and raised further questions about the "secularization" model for understanding religion. Significantly, the world's experience of this new wave of religious action was deeply afforded by media, and media discourses seemed increasingly to be the geography in which global political action was taking place (Hoover 2006).

A fourth wave of change came with the events of 2016, where first the "Brexit" vote in the UK and then election results in Europe and in the United States ushered in a new era in North Atlantic politics. These developments seemed to point to a new political wave, variously called the "new populisms" or "new nationalisms" that roiled settled understandings of the international order. While not explicitly religious in the way that some of the other trends were, these developments nonetheless carried within them both explicit and implicit references to religion, and thus extended and further complicated the problem of thinking about religion in the media age.

An account of the ways that religion and media are interacting and indeed the ways religions are being remade in the media age needs therefore to address these developments. It is my purpose here to lay out some of the groundwork for such a project, one that I hope will encourage the centering of media and religion-or rather the linkage between media and religion-in the theoretical and conceptual repertoire addressed at this changing landscape. 


\section{The Place of the American Model}

I am writing from the U.S., and will center the U.S. case in much of what I present here. I will begin with a word about the U.S. case and its relationship to the situation internationally or globally. There are clearly ways that the U.S. is exceptional, even unique, in relation to religion. It is the most religious OECD country, for example, by nearly any measure (Roof 1999). It is home to a prodigious popular culture of informal religion as well, something that further separates it from other western industrial nations. Its media are largely private and commercial, with a very small—yet very influential—public broadcasting sector. It shares with other western nations, however, a general tendency toward the decline of formal religion. Church attendance, membership, and identification have been declining in the U.S. for the last fifty years, with only replacement-by-birth accounting for significant stability where there is stability. The scale is different from Europe, but the overall trends are similar. In both contexts, and increasingly worldwide, the category of "no religion" is the fastest growing in surveys of religiosity (Alper 2018).

There are important reasons the U.S. case bears watching, even from Europe, though. Most of these reasons have to do with media, and that is the core of what I want to say here. I want to argue that much of what has defined religious change and reformation and whatever resurgence of religion and religious interest is underway has been the "mediation" or "mediatization" of religion. ${ }^{1}$ The difference between these two terms is important. "Mediation" refers to the fact that all religions are in some way "mediated." That is, they involve media of print, or story, or sermon, or art, or dance, or ritual. They must be commemorated and communicated to exist. "Mediatization" means something different. It means that through modern media of communication (and by 'modern' I intend to mean everything from Gutenberg onward) something entirely new is made of religion. It is no longer the case that religion is simply documented or the word carried forth. The essential thing 'religion' is changed by its interaction with media.

What makes the U.S. case significant here is that it is such a hotbed of mediations of religion and is at the same time the singular hegemonic force in the global media and entertainment industries. The prodigious religious marketplace of the U.S. in conjunction with its equally prodigious media marketplace makes it a place that generates a great deal of the media of all forms that finds its way out into an increasingly globalized media sphere, and thus is seen, heard, circulated, and consumed throughout the world. And while it assuredly meets resistance (often significant resistance), it nonetheless constitutes either a model or a provocation to national, regional, and ethno-religious contexts globally. It is both a model of institutional organization and a model of form and content (Collins et al. 2004).

So the U.S. is an important case because of its centrality in global media and its role as a source of religious trends. It is also an important case because it combines 'religion' and 'media' in ways that also become determinative. Its experience with media and religion constitutes a major challenge to the received idea that 'religion' and 'media' are somehow hermetic, independent spheres. In an influential account, Stolow (2005) has argued that we must today begin thinking of religion "as media." Similarly, I have recently suggested that we try to

$1 \quad$ I do not intend to wade into the large and substantive debate about the "mediatization" of religion (see Hjarvard 2008). For my purposes here, a complex or substantive theory of how religions are mediated today is less important than the fact that they are. My account here should help flesh out the extents and limits of this and therefore serve the development of concept and theory. 
understand that the normative constitution of religion today is in its articulation with media (Hoover 2019, 2020).

We should not underestimate the significant role that Protestantism has played and continues to play in the American religious mediascape and thus in the American case. Protestant churches and movements are of course important players in the evolution of mediated religion in North America, as we will see in more detail presently. There is, however, a more profound and fundamental way that Protestantism continues to be active in defining the American media marketplace, creating a situation of great ambiguity in American discourse about media, religion, and values.

It is beyond my purpose here to provide a sufficient account of this history. To state it briefly, though, emerging scholarship on Protestantism elaborates the ways that its course flowed from early Puritan origins, through the 'Great Awakenings', and into the period of confrontation with immigrant faiths (particularly Catholicism), and involved a constant redefinition of the Protestant project (Hollinger 2013). From its early nearly missional roots, it gradually re-made itself as a kind of 'established' faith whose primary purpose was to stand at the center of American culture as the guarantor of that culture. This became a moral as much as a religious purpose, and came to be expressed tacitly and-significant to subsequent political developments-expressed in a project focused on the domestic sphere and on perfecting visions of idealized domestic relations. More importantly for our considerations here, Protestant leaders pursued their goals largely through media, though their preferred vehicles were sermons, tracts, pamphlets, and later readers and textbooks (Fessenden 2006). Public media were essential to this cause, provided those media continued to operate under the tacit control of the Protestant Establishment (Rosenthal 2007; see also Balzell 1987). Protestantism's central role was affirmed well into the mid-twentieth century by its preferred access to the pages of newspapers, newsmagazines, and later the broadcasts of the major commercial television networks. This tacit centrality of Protestantism was, in fact, one of the things most threatened by the emergence of new forms of mediated religion later in the twentieth century.

\section{Media and Religion Converge}

Now, to media and religion. As I've said, I want to argue that it is no longer possible to think of these as separate spheres. In fact, the two have now converged on one another. This convergence is being brought about by important changes in 'religion' and in 'media.'

Religion First. In the latter part of the twentieth century, we have seen a precipitous decline in the power and authority of religious institutions. Public confidence in religion and in clerical authority continues to fall. Participation in religion, at least in the large established religious institutions, continues to decline throughout the North Atlantic West. At the same time, sociologists of religion have seen a marked trend toward increasing personal autonomy in matters of faith. This new approach to faith, variously called "seeking" or "questing," is highly individualistic, and is organized around the logic of the individual crafting a particular or specialized faith directed at their own needs and tastes (Roof 1999; Warner 1993).

This kind of faith is fluid and evolving, and aggressively seeks out new resources, symbols, and experiences to bring into a kind of syncretism of the individual. There is persuasive social theory to explain this trend, largely concentrating on the notion that at this stage of modernity, individuals feel they must take responsibility for crafting their own selves or identities, and that they do so with a kind of autonomy and a suspicion of imposed or received authority 
(Giddens 1991). In the field of religion, this results in a kind of "cafeteria religion" that trusts the self and its own judgments more than it trusts clerics or doctrines (Roof 1999). Religious traditions are not ignored in this. In fact, in some ways they are more important than ever, because as individuals seek to craft their own theology, among the resources they turn to are those that seem to them to be the most 'authentic' and traditional religions, from the Abrahamic faiths to Asian religions, to aboriginal traditions, to 'spirit religions,' to animism, and on and on, which are all potential resources. The world of religion becomes like one large cafeteria. The point is that the logic is centered around the individual and his or her appropriation (we might even say "consumption") of these materials.

At the same time that the world of religion has been changing, so has the world of the media. The most important changes there have been technological, with new developments in the production, transmission, and reception of media, leading to an explosion in channels and sources of media. This has had three important implications. First, the proliferation of channels has broken down the traditional authority that a small number of publishers and broadcasters was able to exercise. Up until the 1960s (and later elsewhere in the West) there were only a few openings through which religions could find their way into media circulation. With the proliferation of channels that has changed. Thresholds have been lowered, terms of access have been eased, and costs have plummeted.

This goes along with the second major implication of media change: a proliferation of channels means that more and more specialized and refined media content can now find its way into circulation. It was once only the 'broad truths,' the common and shared religious conceptions and values that could find their way to air. Now, a dizzying array of religious, spiritual, quasi-religious, implicitly religious, and near-religious claims, productions, symbols, networks, and movements can find their voices in the media marketplace. Small social and political communities of shared interest have formed, and these have become increasingly important, even threatening (as in the case of the August 2019 siege of the German Reichstag and the January 2021 siege of the U.S. Capitol building).

The third major implication of changes in media is the increasing openness on the part of once 'secular' media to accommodate sectarian, religious, and spiritual content. We experience this in large measure as a commodification or popularization of religion. It is a simple result of the forces of the marketplace. As barriers to access to media have been lowered, and more and more sources and channels compete for audiences, the tastes and interests of those audiences become more important. The seeking and questing of the audience stimulates an increasing supply of religiously and spiritually significant material. And new producers emerge with those audiences in mind. This process has accelerated even further with the development of digital and social media.

This has particularly important implications for the future of religion and religious authority. As these 'media-generated' ideas, formations, circulations, and communities form and develop, they increasingly become new forms of religious authority as well. What stands for or accounts for religion in these commodified markets can be nothing more important than what 'works' or what is 'most popular.' Authoritative doctrinal or historical sources no longer matter as much.

With this increasing commodification (a kind of 'mediatization') of religion come some important dimensions or frames. First among these is the sense that, in the media, religion is more and more an aesthetic practice. Religion scholars have talked about a shift from 'religion' to 'the religious.' This refocuses our attention on the attributes of those things that 
circulate around religion, and taste and aesthetics play an increasing role. This is more critical when we remember that the new media are more and more visual in their logics and representations. Second, religions today thus face the challenge of an autonomous sphere of practice-the media-which operates according to its own logics and which becomes more and more definitive of what is possible in the circulate of ideas, truth claims, and values ${ }^{2}$.

\section{Implications for Religious Authority}

For religious institutions and authorities, this contest is felt in some specific ways. First, religions increasingly lose control over their own symbols. The media and celebrity culture can now define the meanings of religious signs. Traditional teachings are contested by popular teachings. For example, the American popular music star Madonna made a career of appropriating, re-appropriating, and resisting the symbols of the Catholic faith of her youth, and then moved on to the project re-defining and commodifying the Jewish tradition of Kabbalah.

Second, in this contest, clearly some religions will 'win' and some will 'lose.' The fundamental fact is that to exist today, institutions that wish to be active in the public sphere must exist in the media. Some religions and religious traditions are better at this than others. The roots of American Evangelicalism, for example, are very much in media. The frontier and urban revivalism of the nineteenth century that has so defined American popular religion were infused with media and media commodities (admittedly in rudimentary form), and Evangelicals have eagerly embraced each new medium to emerge, from radio to film to television, and now the internet. Other religions, particularly those with greater concern for structure and authority, have been slower to adopt these modern media.

Third, these trends increasingly 'relativize' religious authority. This is probably the most profound and far-reaching implication of these trends. As the media interpose themselves in the production and circulation of religious and spiritual resources, and as this ever more extensive marketplace of mediated religious 'supply' continues to evolve, particular religions and authorities become less important and less significant. More importantly, perhaps, they also become more 'horizontalized' in that the once pre-eminent histories and institutions (the 'historic' faiths) exist in the media marketplace alongside a wide range of other sources from which increasingly autonomous consumers simply pick and choose. That is not to say the Vatican or Lambeth Palace (the seat of the Archbishop of Canterbury) or the German Evangelische Kirche (EKD) have entirely disappeared or lost their distinctiveness; it is to say that the rules have been radically changed.

Fourth, this means that traditional religions today must exist alongside a growing heterogeneous marketplace of religion and spirituality that is no longer concerned with form, doctrine, tradition, and history. Instead, what religion scholars call 'implicit' or 'banal' or 'informal' religion flourishes. Whether this flourishing is at the expense of traditional religion is a matter for some study and debate. What it does mean is that the category we used to think of as 'civil religion' is no longer just about the commemoration of important secular or quasi-religious events of state or of mourning? It now needs to be expanded to include a wide range of less formal, more popular movements, images, and practices that increasingly encroach on the turn of formal religion.

2 For a thorough discussion see Hoover (2016), Chapter 1. Much of the following material is condensed from this work. 


\section{Globalization, the New Politics, and Challenges to Settled Authority}

The most recent wave of religious evolution, that was made obvious by the events of 2016 and after, are legible in relation to the ongoing project of neoliberal globalization. Significant to my argument here, the media are central to the ongoing development of globalized economics, cultures, and politics. Likewise, an account of contemporary global religions needs to articulate religion in relation to media (S. Hoover and Echchaibi 2021). I have argued elsewhere that that the new populism is best understood as a kind of identity discourse, focused around new forms of resurgent nationalism. These nationalist impulses are deployed through mediations that craft aspirational imaginaries focused on 1) nostalgia for remembered pasts, 2) neo-traditionalist narratives of gender relations and the structure of the domestic sphere, and 3) a desire to once again "mark" the culture with religion (Hoover 2019). Further, I suggest that media are central to these projects as they can so effectively locate such projects of imagination. Finally, much of this discourse invokes imaginaries of both religion and secularity, placing them in a powerful dialectical relationship with one another.

In relation to the mediation of these neo-populist movements, and in relation to the broader development of the mediation of religion and the gradual dispersal of religious action into public spheres of mediated commodities, traditional religious institutions find themselves facing powerful challenges to their authority. These challenges, though, are not direct (though there are some of those) so much as they are the indirect consequences of cultural processes that are taking place elsewhere according to their own sources and logics. They are also consequences of the nature and constitution of contemporary political economies of mediation and their logics. For settled religious authorities, a number of challenging conditions present themselves (Hoover 2016).

First, it is no longer possible to have a 'private conversation.' Where once it was possible to think of national, regional, ethnic, and religious communities and institutions as bounded entities, today all is open to view. The so-called "Danish cartoon controversy" of 2005 happened in part because the actions of a newspaper in Denmark, focused on the situation with Muslims living in Denmark, found their way onto the global stage, with consequences well beyond what the editors expected. The sex-abuse scandals in the Catholic church cannot be confined to a specific national context or a diocese, or indeed be held within the Church. They become public issues, open to public scrutiny and public debate worldwide.

Second, in the global context, religious institutions are even less able to control their own symbols or their own messages outside the transmissions and framings of the media. It is nearly impossible for religious voices to convey messages to particular audiences when all is open to scrutiny and when the media will always frame and condition the nature of those messages.

Third, globalization means that religion and religions are increasingly transnationalized. This is felt most concretely in the way that media make it possible for immigrant communities worldwide to maintain close ties with home, but also in the emergence of truly transnational religious voices, discourses, and movements. In Christianity, the global spread and growth of Pentecostalism is both a function of media and of cultural and economic globalization. Likewise, in Islam, both the conservative forces of Wahabism and the moderating forces of new Muslim popular cultures emergent in East and West are examples of the transnationalization of religion under a regime of globalization with media at its core. 
Fourth, the rise of the media marketplace as a global context means that informal, popular, and non-institutional expressions of religion can also come to the fore transnationally, adding to the challenges faced by religious institutions and authorities. The most prominent current examples in Islam are large and well-funded "televangelism ministries" that have emerged. Many of the most popular of these programs and figures are not clerics or even people with formal theological training, but entrepreneurs motivated to reach a global Muslim audience with services intended to work around the implied conservatism and anti-modernism of the various clerical establishments of Islam (Fanack 2017). Doing so, they provide something entirely new: a transnational Muslim voice or perspective, at the same time that they relativize authority. Alongside these large, formal broadcasts have emerged a growing array of informal, popular, user-generated websites, broadcasts, listservs, and other digital projects, linking a global Muslim youth culture in an unprecedented way. In Christianity, several of the "televangelism" ministries that arose as part of the neo-evangelical revival of the late twentieth century still exist, along with new channels and voices. Among the latter are sources such as the feature film productions of (former Trump adviser and global Catholic activist) Steven Bannon, and the Russian Tsargrad TV that is described as a cross between American televangelism and the American Fox News channel (and to which I will return, Hoover 2019).

This transnationalism thus extends beyond simply the worlds of religious institutions and religious practices. As the politics of the post-Brexit and post-Trump eras show, religion is articulated into domestic and international politics in entirely new ways. Religious and quasireligious meanings, tropes, and symbols today center new forms and circulations of politics (Sauerbrey 2021). These are neither purely 'religious' nor purely 'political' nor purely 'media.' They transcend these boundaries and make problematic our traditional ways of thinking about these relations (S. Hoover 2021; S. Hoover and Echchaibi 2021).

Religious institutions and authorities thus face, in the twenty-first century, a radically altered media, political, and public context. While they once may have been able depend on deference in public and political contexts that might naturally have flowed to them as historically legitimate forces, their authority and influence has faded. Religious participation and attendance continues to decline throughout the North Atlantic West. Second, religion is increasingly a function of its mediation. It no longer makes sense to think of religion and media as separate spheres with the essential questions being the effects of one upon the other. No, today media and religion are increasingly "articulated" with one another (Hoover 2020; S. Hoover and Echchaibi 2021). Religions are known today through their mediations and representations. They increasingly exist in commodified marketplaces of symbolic exchange. Their center of gravity has shifted away from text, doctrine, and structure, and toward elastic circulations of mediated resources.

This does not mean that religion has disappeared entirely or that religious authority has ceased to function. It would be too easy to simply pronounce the 'end of the age' for religion as we have known it. This would be too easy and too facile. Religious institutions do persist, and religious authority, even academic and clerical authority, also persists. Religion remains significant in that it persists even in the current age of re-made North Atlantic politics. And religious authority also persists, though it no longer seems to work quite the way it once did.

\section{Differing Expressions of Authority}

Theories of religious authority (such as those based on Weber's (2013) classic formulation) 
think of authority as a kind of 'first cause.' That is, authority speaks from settled and foundational contexts of knowledge of history. Instead, authority today is involved in social, cultural, and political action in much more strategic and tactical ways. It is appealed to or appropriated as much as it speaks for itself. And, to the extent that specific authoritative voices from religion enter circulation, it is in this conditional, tactical way. In relation to politics, we can see different versions of this in specific cases in Catholicism, Protestantism, and Orthodoxy.

In Catholicism, Pope Francis entered global consciousness in 2013 as a surprise. Seemingly coming from nowhere, he quickly emerged as an unusual voice, openly breaking with the conservatism of his two predecessors. He became a cause célèbre for progressive and fallenaway Catholics worldwide. But this reputation may well be a media construction. Some have pointed out that he has found a way to speak in media that embraces change, while on the ground, some key things have not changed (Reese 1999). And in the central crisis facing the church over the past decades - the sexual-abuse scandal-he appeared slow to move official policy or practice (Green 2019). Even the most positive portrayals of his influence have focused on the way he has articulated the church into media circulation (Reese 1999).

Meanwhile, Protestantism is deeply involved in the current political moment in the United States. A great deal of journalistic attention has been paid to the level of Evangelical support for Donald Trump. The seeming contradiction of this is a matter of interest and speculation (Berger 2019; French 2019, 2019). Trump would appear to be the antithesis of the kind of president abstemious Protestants would support. Yet, he boasts a conservative religious reference group that includes many prominent Evangelicals, such as Franklin Graham (the son of Billy Graham) and Jerry Falwell, Junior. One of them, evangelist Paula White, is widely described as Trump's personal pastor. There are a variety of theories as to how this contradiction came into being. There is no doubt that Trump's administration did many things that please the Evangelical community, but at the same time, the situation led to a great deal of turmoil among conservative Christians, with younger Evangelicals in particular coming to question the easy alliance between some leaders and Trump. Another theory is that Trump represented a present day "Cyrus" figure (Stewart 2018). King Cyrus was the Persian King who freed the people of Israel. He was not himself a believer but he was the deliverer of the believers. Trump could be seen in similar ways and was portrayed in this way in a film titled The Trump Prophecy.

Significant to my point here, the Evangelical figures who gathered around Trump were notably not connected with major denominations or established religious bodies. They are independents, connected with independent institutions and ministries which are nonetheless powerful institutions on their own. The evangelical resurgence of the late twentieth century involved the emergence of such organizations and movements, often afforded by media (Fea 2019). But media and mediation are more significant to conditions today in that these evangelical leaders seem particularly attuned to the way that their access to Trump continues a legacy of public ascendancy and image-making by the evangelical community (Lindsay 2008). For these leaders, this access and public profile is the main point. This is a new and interesting turn in the long arc of American Protestant accommodation to media (Hoover 2019, 2020). It is no longer necessary for media to be seen as instruments of ministry or outreach. Instead, these Protestant leaders are comfortable with direct participation in the mediated political marketplace, in spite of the risks to their authority and credibility (Fine 2018).

In Russia, institutional religion interacts with politics and media in a way that echoes these other two cases, and carries valences of the forces evident there. The Orthodox church has be- 
come an important political tool for Putin's presidency. The Orthodox prelate, Patriarch Kirill, has become an important figure to Putin's project of shoring up certain Russian political constituencies. While Kirill's support of Putin is not absolute, he has nonetheless welcomed the attention. Putin, meanwhile, has begun to portray Russia as an important center of true Christianity. The themes he stresses are entirely familiar to my argument here: nostalgia, gendered domestic ideals, and the religious "marking" of the Russian culture (Ellis and Kolchyna 2017; Staehle 2021). This situation is not without its contradictions and ambiguities. Significantly, the Russian church and the Evangelicals who support Trump have begun to weave an alliance centered around their shared interests (Burgess 2018).

Media enter into the Russian situation in a particular way with the establishment of the Moscow-based television channel, Tsargrad TV, which has been described as a combination of an American televangelism ministry and the American Fox News channel (Fine, 2018). It is deeply interconnected both with Orthodoxy (though it is independent of the Church) and with emergent politics. One of its founders is claimed to have been directly involved in paramilitary actions in Eastern Ukraine (Ellis and Kolchyna, 2018). Since its inception Tsargrad TV has the potential to act as a 'third force' in contemporary Russian politics, at one and the same time promoting a conservative and nostalgic view of Orthodoxy's place at the center of Russian culture.

\section{Conclusion: The Changing Face of Media and Religion}

These three cases show the challenge of accounting for the ever-changing mediascape and its implications for the world of religion. Each is unique, but there are some shared features. First, the articulation of media and religion, what Stolow (2005) called "media as religion," has continued to move ahead. The media sphere today is an important context for the evolution of religion and that religion is largely known and activated through its mediations. A wide variety of religious and religiously-inflected media circulations today compete with-and are in the main overwhelming-the authority of the traditional institutions. Second, as institutions and their authority go about their business today, they face a media sphere that not only competes with them, but increasingly defines them and creates the conditions through which they act. Third, forces and actors that are independent of the traditional institutions are increasingly finding voice through and with media, and these are also coming to shape the conditions under which religious authority is expressed and understood today.

This is ever more important as the new politics in the North Atlantic West is itself engaging and articulating religion and is doing so in imaginative (and often dangerously so) registers that largely depend on media circulations (Hoover 2019, 2020, @hoover_media_2021). Many of these forces can be described as "religiously nationalistic" in that they focus on the agendas of religious nationalism identified by Roger Friedland (2002). Friedland suggest that the dimensions I have described here are, in fact, deeply rooted in longer-term-even anthropological—sensibilities of religious nationalism. The desire of conservative Catholics who oppose Pope Francis to nostalgically re-assert traditionalist sexual mores, the agendas of the Evangelical leaders who gathered around Trump, and Tsargrad TV, all share in common these objectives of nostalgia, traditionalist gender relations, and a desire to 'mark' the culture with religion.

We can see, then, a powerful force of religion in contemporary politics, but it is not a force rooted in traditional institutional authority. Neither is it something that is based entirely 
in religion's use of 'powerful' media. Instead, it must be seen as the latest turn in the long evolution, across history, of relations between 'religion' and 'media.' This has not become a seamless relationship, where the media today are religion. Instead, it is a complex and layered situation which demands keen analytical tools to be able to understand and account for the various and significant ways that religion and media interact. Accounts of media and religion can too easily and facilely focus on the ways that media have become religion in many contexts. But we should not forget that traditional religion-and traditional religious institutions-continue to exist. What they do, and more importantly what they are able to do or have the authority to do, in an age where religion is being drawn into politics in new and in many ways troubling ways, is a very important challenge for them and question for scholars who wish to understand and interpret contemporary culture and politics.

\section{References}

Alper, Becka. 2018. "Why America's 'Nones' Don't Identify with a Religion.” FactTank. Washington, D.C.: Pew Research Center. https://www.pewresearch.org/fact-tank/2018/08 /08/why-americas-nones-dont-identify-with-a-religion/.

Balzell, Digby. 1987. The Protestant Establishment: Aristocracy and Caste in America. New Haven: Yale University Press.

Berger, John. 2019. "Brought to Jesus: The Evangelical Grip on the Trump Administration." The Guardian, January 11, 2019.

Burgess, John. 2018. "The Unexpected Relationship Between U.S. Evangelicals and Russian Orthodoxy." Christian Century, August 2, 2018. https://www.christiancentury.org/artic le/features/unexpected-relationship-between-us-evangelicals-and-russian-orthodox.

Calhoun, Craig, Mark Jurgensmeyer, and Jonathan van Antwerpen, eds. 2011. Rethinking Secularism. New York: Oxford University Press.

Collins, Erin, Martin Jensen, Peter Kanev, and Mathew MacCalla. 2004. "Shifting Power: U.S. Hegemony and the Media." Journal of International Studies 2: 21-49.

Ellis, Bryan, and Viktoryia Kolchyna. 2017. "Putin and the Triumph of Christianity in Russia." Al Jazeera Online, 2017. https://www.aljazeera.com/blogs/europe/2017/10/putintriumph-christianity-russia-171018073916624.html.

Fanack. 2017. "Amr Khaled: Egypt's Once Hip Preacher Turned Symbol of the Past." Fanack, 2017. https://fanack.com/egypt/faces-of-egypt/amr-khaled/.

Fea, John. 2019. "Why Do White Evangelicals Still Staunchly Support Donald Trump?" Washington Post, April 5, 2019.

Fessenden, Tracy. 2006. Culture and Redemption: Religion, the Secular, and American Literature. Princeton: Princeton University Press.

Fine, Thomas. 2018. "Tsargrad TV the Fox News of Russia." Medium, February 25, 2018.

French, David. 2019. "Evangelicals Are Supporting Trump Out of Fear, Not Faith." Time Magazine, July 18, 2019.

Friedland, Roger. 2002. "Money, Sex, and God: The Erotic Logic of Religious Nationalism." Sociological Theory 20 (3): 381-422.

Giddens, Anthony. 1991. Modernity and Self-Identity: Self and Society in the Late Modern Age. Stanford: Stanford University Press.

Green, Emma. 2019. "Why Does the Catholic Church Keep Failing on Sexual Abuse?" The Atlantic Monthly, 2019. 
Hjarvard, Stig. 2008. "The Mediatization of Religion: A Theory of the Media as Agents of Religious Change." Northern Lights 6: 9-26.

Hollinger, David. 2013. After Cloven Tongues of Fire: Protestant Liberalism in Modern American History. Princeton: Princeton University Press.

Hoover, Stewart. 2016. Religion in the Media Age. London: Routledge.

- 2019. "Modes of Understanding of the Religion 'Object' in North Atlantic Modernity." Journal of Religion and Transformation 5: 351-75.

— 2020. "Myth Today: Reading Religion into Research on Mediated Cultural Politics." International Journal of Communication 14: 4508-32.

—. 2021. "Media, Religion, and Politics in the Capitol Siege (Part 3)." StewartHoover's Blog (blog). 2021. stewarthoover.wordpress.com/2021/01/31/media-religion-andpolitics-in-the-capitol-siege-part-3/.

Hoover, Stewart, and Nabil Echchaibi, eds. 2021. Media and Religion: The Global View. Berlin: DeGruyter.

Hoover, Stewart M. 2006. Religion in the Media Age. Religion, Media and Culture. London/New York: Routledge.

Lindsay, Michael. 2008. Faith in the Halls of Power. New York: Oxford.

Marsden, George. 1984. Evangelicalism and Modern America. Grand Rapids: Eerdmans.

Miller, Donald, Kimon Sargeant, and Richard Flory, eds. 2013. Spirit and Power: The Growth and Global Impact of Pentecostalism. New York: Oxford.

Reese, Thomas. 1999. "Pope to Church: Bring Abusers to Justice." Religion News Service, 1999. https://religionnews.com/2019/01/02/pope-to-church-bring-abusers-to-justice/.

Roof, Wade Clark. 1999. Spiritual Marketplace: Baby Boomers and the Remaking of American Religion. Princeton: Princeton University Press.

Rosenthal, Michele. 2007. American Protestants and the Media: Response to a New Medium. New York: Palgrave Macmillan.

Sauerbrey, Anna. 2021. "Far Right Protesters Stormed Germany's Parliament: What Can America Learn?” New York Times, January 8, 2021. https://www.nytimes.com/2021/01/08 /opinion/germany-parliament-us-capitol.html?referringSource $=$ articleShare.

Staehle, Hanna. 2021. Media and Religion in Russia: How Digital Criticism Is Driving Transformation of the Russian Orthodox Church. London: Routledge.

Stewart, Katherine. 2018. "Why Trump Reigns as King Cyrus." New York Times, December 31, 2018.

Stolow, Jeremy. 2005. "Religion and/as Media." Theory, Culture \& Society 22 (4): 119-45.

Warner, R.Stephen. 1993. "Work in Progress Toward a New Paradigm for the Sociological Study of Religion in the United States." American Journal of Sociology 98 (5): 1044-93.

Weber, Max. 2013. Economy and Society. Berkeley: University of California Press. 